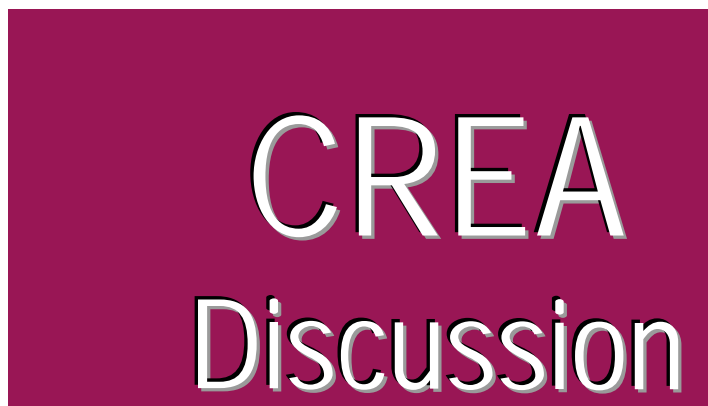
Paper

\title{
2013-24
}

Center for Research in Economic Analysis

University of Luxembourg

\section{Who benefits from partial tax coordination?}

available online : http://wwwfr.uni.lu/recherche/fdef/crea/publications2/discussion_papers

Yutao Han, CREA, Université du Luxembourg

October, 2013

For editorial correspondence, please contact: crea@uni.lu

University of Luxembourg

Faculty of Law, Economics and Finance

162A, avenue de la Faïencerie

L-1511 Luxembourg 


\title{
Who benefits from partial tax coordination?*
}

\author{
Yutao $\operatorname{Han}^{\dagger}$ \\ CREA, University of Luxembourg
}

\begin{abstract}
In this paper, we investigate whether partial tax coordination is beneficial to countries within and outside a tax union, in which countries are supposed to compete in taxes and infrastructure. Our results demonstrate that, a subgroup of countries agreeing on a common tax rate, can harm both member and nonmember states. This is in contrast to the classical findings that partial tax harmonization is Pareto improving. When a minimum tax rate is imposed within a tax union, we demonstrate that it does not necessarily improve the welfare of the member countries. Moreover, both the high tax and low tax countries can be worse off. This conclusion is at odds with the classical result that a high tax country benefits from the imposition of a lower tax bound.
\end{abstract}

Keywords: Tax competition, infrastructure competition, partial tax coordination, social welfare

JEL classification: H21; H87; H73; F21; C72

*I appreciate the valuable discussion of this work with Patrice Pieretti, Benteng Zou, and the participants of the workshop at university of Luxembourg (2013). Of course, all eventual mistakes and errors are mine.

${ }^{\dagger}$ Corresponding author: 162a, avenue de la Faiencerie, L1511 Luxembourg, Luxembourg. E-mail: yutao.han@uni.lu 


\section{Introduction}

The issue of corporate tax harmonization has been debated in the European Union (EU) since the European Economic Community was established. Specifically, in 2003 the EU Council adopted a voluntary Code of Conduct against harmful tax competition, and more ambitious proposals for corporate tax harmonization have been proposed, including the introduction of a single EU corporate tax (see Conconi et al., 2008). The primary motivation for this is that the growing economic integration has increased international mobility of capital and labor, which increasingly places downward pressure on national tax policies. Consequently, many authors have noted that independent governments engage in wasteful competition over scarce capital through inefficiently low tax rates and public expenditure levels (Zodrow and Mieszkowski, 1986; Wilson, 1986). Accordingly, tax coordination is proposed to correct the alleged inefficiencies caused by tax competition, as is highlighted in the tax literature (for systematic reviews, see Wilson, 1999; Wilson and Wildasin, 2004; Boadway and Tremblay, 2011).

However, neither a common corporate tax rate nor a minimum tax rate ${ }^{1}$ has been successfully implemented in the $\mathrm{EU}^{2}$. Konrad and Schjelderup (1999) argue that some countries may prefer a low tax status ${ }^{3}$. This is exemplified by tax havens, which have a commercial interest in not harmonizing their taxation levels. Moreover, for political reasons, it is also not always possible to agree on full tax coordination (Marchand et al., 2003). Thus, as an alternative, partial tax coordination seems to be a more realistic policy option. Partial coordination generally describes a situation in which each individual agent cooperates with a subset of others but not with everyone in the economy

\footnotetext{
${ }^{1}$ The Ruding Committee (1992) proposed a common minimum corporate tax rate for the EU .

${ }^{2}$ Keen and Konrad (2012) argue that regional blocs other than the EU (Central America, East and South Africa and elsewhere) have also sought to reach agreements limiting corporate tax competition among themselves, but as in EU, with limited success.

${ }^{3}$ Burbidge et al. (1997) theoretically demonstrated that with more than two states, incomplete federation can be the unique equilibrium by assuming endogenous coalition formation.
} 
or the society (Beaudry et al., 2000). The Enhanced Cooperation Agreements (ECAs) ${ }^{4}$ among EU member states can be regarded as an example of partial coordination ${ }^{5}$.

The issue of partial coordination has been addressed in the tax competition literature. Konrad and Schjelderup (1999) demonstrated that in the standard tax competition framework, tax harmonization among a subset of countries is Pareto improving if tax rates in the initial fully noncooperative Nash equilibrium are strategic complements. In addition, Conconi et al. (2008) $)^{6}$ suggest that, if capital is sufficiently mobile, partial tax harmonization benefits all countries involved relative to both global and no harmonization.

Many authors argue that jurisdictions compete not only in taxes but also in the provision of infrastructure (see Justman et al., 2002; Hindriks et al., 2008; Zissimos and Wooders, 2008; Pieretti and Zanaj, 2011). However, the existing literature on the desirability of partial tax coordination is primarily based on the assumption that countries solely compete in tax rates. In the present study, we investigate whether partial tax coordination can benefit the countries within and outside the tax union when countries use taxes and infrastructure strategically ${ }^{7}$. One closely related contribution to our work is Sørensen ${ }^{8}$ (2004), who shows that, when countries are symmetric, the outsider enjoys a larger welfare gain from a binding minimum tax than countries in the union.

${ }^{4} \mathrm{EU}$ member states are divided about whether or not to pursue corporate tax harmonization. For this reason, a subset of European countries has recently been institutionalized in the form of Enhanced Cooperation Agreements (ECAs) under the treaties of Amsterdam (1997) and Nice (2003). An ECAs occurs if not all 27 Member States agree upon cooperation, but only a subgroup (or coalition) among them (with a minimum of eight).

${ }^{5}$ Policy coordination among EU member states, rather than coordination with all of the countries in Europe, can be regarded as another example of partial coordination.

${ }^{6}$ The paper analyzes partial tax coordination in a context with downward pressure on tax rates due to tax competition on the one hand and upward pressure on tax rates due to time-consistent confiscatory taxation on the other.

${ }^{7}$ In our paper, we do not focus on the stability of the tax union. We simply assume that the union is formed by other factors outside the context of the tax competition problem.

${ }^{8}$ The model in the paper incorporates various forms of taxations, a public consumption good, infrastructure provision, and a redistributive lump sum transfer. 
Given cross-country asymmetries ${ }^{9}$, the welfare gains from regional tax coordination mainly accrue to countries with high initial tax rates.

However, our setting differs from that in Sørensen (2004). First, he considers an egalitarian social welfare function ${ }^{10}$. In our paper, we do not consider the redistributional aspects of tax policies, and thus we assume that the governments maximize social welfare without concern for inequality. Therefore, we can exclusively focus on the impact of policy coordination on social welfare. In addition, all of the strategic variables are related via a budget constraint in Sørensen (2004), hence the equilibrium taxes and public expenditures crucially depend, as Wildasin (1991) noted, on which instrument is strategically selected ${ }^{11}$. However, recent empirical research (Hauptmeier et al., 2012) demonstrates that jurisdictions use strategic tax rates and public inputs independently to compete for capital. Our model does not have this budget constraint ${ }^{12}$, and hence taxes and expenditures are two independent strategic variables ${ }^{13}$.

In the present paper, we investigate the welfare implications of partial tax coordination when countries compete in taxes and infrastructure ${ }^{14}$. To this end, we assume that only a subgroup of all countries considered forms a union. Moreover, the union's member states only coordinate their tax policies while still compete in the infrastructure provision. This implies that the union countries, while coordinating their tax rates, are able to adjust their infrastructure policies to attract foreign capital. In addition, the

\footnotetext{
${ }^{9}$ Sørensen (2004) assumes that countries differ in pure profit shares, foreign ownership shares, initial endowments, and social preferences regarding redistribution.

${ }^{10}$ The government in each country is concerned with the average individual welfare level and the dispersion of individual utilities around this mean.

${ }^{11}$ Koethenbuerger (2011) also argues that models of local public finance predominantly assume that local governments set taxes while expenditures are residually determined via the budget constraint.

${ }^{12}$ This is in the same vein as Hindriks et al. (2008), Zissimos and Wooders (2008), Pieretti and Zanaj (2011), and Hauptmeier et al. (2012).

${ }^{13}$ The only condition we require is that the budget is non-negative, which is the case because the jurisdictions are assumed to impose a lump sum tax to finance public expenditures if necessary, as assumed in Hindriks et al. (2008).

${ }^{14}$ These infrastructure investments may represent material or immaterial public goods such as laws and regulations protecting intellectual property and specifying accurate dispute resolution rules.
} 
union competes in taxes and infrastructure with the rest of the world.

Two partial coordination devices are considered successively. We first discuss the welfare implications of tax harmonization (a common tax rate) within the union. Because a common tax rate may prove difficult to implement, we consider the case in which a minimum tax rate is imposed within the union. We then analyze the related welfare effects.

Our results show that a subgroup of countries agreeing to a common tax rate can have adverse consequences for both union and nonunion countries. This is in stark contrast with Konrad and Schjelderup's (1999) finding that partial tax harmonization is Pareto improving when jurisdictions solely compete in taxes. Our result also differs from that in Sørensen (2004), in which partial coordination leaves all countries better off, assuming countries compete in both ${ }^{15}$ taxes and infrastructure. In addition, we demonstrate that both high tax and low tax countries can be worse off when a lower tax bound is applied within the tax union. This result is at odds with Sørensen (2001, 2004), who concludes that the imposition of a minimum tax rate benefits the high tax country and harms the low tax country.

The paper is organized as follows. In the next section, we study the welfare implications of partial coordination when countries only compete in taxes. In section 3 , we derive optimal strategies from tax and infrastructure competition for each government. Section 4 then compares social welfare with and without partial tax harmonization. The welfare implications of a minimum tax rate are considered in section 5. Section 6 concludes.

\section{The benchmark}

As a benchmark, we first study the welfare implications of partial tax coordination assuming countries compete only by taxes. As in Sørensen (2004), two cases are con-

\footnotetext{
${ }^{15}$ As we argued above, in his paper, taxes and infrastructure are not independent variables.
} 
sidered. We assume that a tax union implements a common tax rate with symmetric competing countries. When the countries are asymmetric, we assume that a minimum tax rate is imposed ${ }^{16}$ in the union.

\subsection{Partial coordination with symmetric countries}

Consider three identical countries $i=1,2,3$. They compete in taxes to attract perfectly mobile capital from the rest of the world. There is no domestic ownership of capital ${ }^{17}$. We assume that the jurisdictions tax capital to extract rents from the capital owners. The total stock of capital is fixed and normalized to 1 . In each country, there is a representative firm and the number of residents is normalized to one. The government in country $i$ selects a unit tax rate $t_{i}$, which is source-based. Capital locates in the country where profits are highest.

The production of the representative firm in each country is given by the function $F_{i}\left(k_{i}\right)$, which is increasing, twice continuously differentiable and concave in the level of capital $k_{i}(i=1,2,3)$. Under perfect mobility, the allocation of capital will equate its net return $\rho$ across all jurisdictions. This net return is assumed to be positive. We thus obtain the following equality

$$
\rho=f_{1}\left(k_{1}\right)-t_{1}=f_{2}\left(k_{2}\right)-t_{2}=f_{3}\left(k_{3}\right)-t_{3},
$$

where $f_{i}$ is the marginal product of capital in country $i$. The above arbitrage condition determines the amount of capital in each country $k_{i}(i=1,2,3)$. By setting an appropriate tax rate $t_{i}$, each government maximizes the welfare $W_{i}$ of its residents, the sum of the return to the immobile factor and the tax revenue,

$$
W_{i}=F_{i}\left(k_{i}\right)-f_{i}\left(k_{i}\right) k_{i}+t_{i} k_{i},
$$

\footnotetext{
${ }^{16}$ To the best of our knowledge, the welfare implications of imposing of a minimum tax rate among a subset of countries has not been studied when they solely compete in taxes.

${ }^{17}$ This assumption is made in several contributions (see, for example, Hindriks et al., 2008; Kempf and Rota-Graziosi, 2010).
} 
which is rebated to the residents. For reasons of tractability, we assume that the production function takes the form ${ }^{18}$

$$
F_{i}\left(k_{i}\right)=a k_{i}-\frac{b}{2} k_{i}^{2},
$$

where $a>0$ is a shift parameter of the production function and $b>0$ is the rate of decline of the marginal product of capital relative to $k_{i}$.

The parameter $b$ plays a critical role in our model. The higher the value of $b$, the lower the productivity of capital for a given amount of invested capital. As Machlup (1991) pointed out, the scarcity degree of complementary factors influences the declining rate in marginal productivity. In other words, the scarcer these factors are the higher the value of $b$ should be.

Because the net return of capital must be nonnegative, we impose the condition ${ }^{19}$ $\frac{a}{b}>k_{i}$. The welfare function of country $i$ becomes

$$
W_{i}=\frac{b}{2} k_{i}^{2}+t_{i} k_{i} .
$$

From (1), the capital invested in each jurisdiction is

$$
k_{1}^{*}=k_{2}^{*}=k_{3}^{*}=\frac{1}{3} .
$$

Maximizing the welfare of each country yields the following optimal tax rates

$$
t_{1}^{*}=t_{2}^{*}=t_{3}^{*}=\frac{b}{6} .
$$

The corresponding payoffs are

$$
W_{1}^{*}=W_{2}^{*}=W_{3}^{*}=\frac{b}{9} .
$$

In what follows, we assume that countries 1 and 2 form a tax union and set a common tax rate $t^{c}$ that maximizes the total welfare of the union. Country 3 remains outside and observes the coordination inside the union. Therefore, the tax union and

\footnotetext{
${ }^{18}$ Note that a linear quadratic production function is assumed by several authors, such as Bucovetsky (1991, 2009), Peralta and Ypersele (2006), and Itaya (2008).

${ }^{19}$ In what follows, we assume that $a$ is sufficiently large.
} 
country 3 compete for mobile capital by selecting taxes $t$ and $t_{3}$ noncooperatively. The amount of capital located in each economy is then $k_{1}=k_{2}=\frac{1}{4}$ and $k_{3}=\frac{1}{2}$. Solving the game, the equilibrium tax rates are

$$
t^{c}=\frac{b}{2}, t_{3}^{c}=\frac{b}{4}
$$

The union as a whole faces a lower elasticity of capital supply than the individual member states. Thus, the uniform tax rate is higher than the noncooperative equilibrium rates, $t^{c}>t_{i}^{*}(i=1,2)$. Because tax rates are strategic complements, country 3 sets a higher tax rate than in the noncooperative case, $t_{3}^{c}>t_{3}^{*}$. The resulting payoffs are

$$
W_{1}^{c}=W_{2}^{c}=\frac{5 b}{32}, W_{3}^{c}=\frac{b}{4} .
$$

Comparing welfare levels with and without coordination, it is easy to see that

$$
\begin{aligned}
W_{i}^{c}-W_{i}^{*} & =\frac{13}{288} b>0, i=1,2, \\
W_{3}^{c}-W_{3}^{*} & =\frac{5}{36} b>0 .
\end{aligned}
$$

That is, partial tax harmonization improves the welfare of all of the countries if we only consider pure tax competition. This result is consistent with classical results (see Konrad and Schjelderup, 1999).

\subsection{Partial coordination with asymmetric countries}

Countries can be asymmetric in many respects (see Bucovetsky, 1991; Wilson, 1991; Keen and Kanbur, 1993), such as size, initial resource endowments, and productivity. In our paper, we assume that countries are heterogeneous in their degree of development, which is reflected by a country specific productivity parameter. For simplicity ${ }^{20}$, we assume ${ }^{21}$ that countries 2 and 3 are identical but characterized by a higher level

\footnotetext{
${ }^{20}$ More generally, we could consider that all the countries differ in terms of their level of development. However, this would unnecessarily complicate the calculations without providing further insight.

${ }^{21}$ For a similar assumption, see Bucovetsky and Smart (2006), Burbidge and Cuff (2005), and Peralta and van Ypersele (2005).
} 
of development than country 1 . This is assumed without loss of generality. We thus assume that $F_{1}\left(k_{1}\right)<F_{2}\left(k_{2}\right)=F_{3}\left(k_{3}\right)$. The different production functions take the following form

$$
\begin{aligned}
& F_{1}\left(k_{1}\right)=a k_{1}-\frac{b}{2} k_{1}^{2}, \\
& F_{i}\left(k_{i}\right)=(a+\varepsilon) k_{i}-\frac{b}{2} k_{i}^{2}, i=2,3,
\end{aligned}
$$

where the shift parameter $\varepsilon$ is positively signed. We first solve the noncooperative game among the three jurisdictions. We then analyze the welfare effects of the lower bound on taxes.

When all countries compete, solving ${ }^{22}$ for the first order conditions (FOCs) leads to the following equilibrium taxes

$$
t_{1}^{n}=\frac{b}{6}-\frac{2 \varepsilon}{9}, t_{2}^{n}=t_{3}^{n}=\frac{b}{6}+\frac{\varepsilon}{9} .
$$

It follows that $k_{1}^{n}=\frac{1}{3}-\frac{4 \varepsilon}{9 b}$ and $k_{2}^{n}=k_{3}^{n}=\frac{1}{3}+\frac{2 \varepsilon}{9 b}$. The less developed country attracts less capital relative to the advanced one, $k_{1}^{n}<k_{2}^{n}=k_{3}^{n}$. The tax rate in country 1 is also lower due to its low productivity, $t_{1}^{n}<t_{2}^{n}=t_{3}^{n}$. The social welfare levels of the three countries are

$$
W_{1}^{n}=\frac{(3 b-4 \varepsilon)^{2}}{81 b}, W_{2}^{n}=W_{3}^{n}=\frac{(3 b+2 \varepsilon)^{2}}{81 b} .
$$

Now we assume that countries 1 and 2 agree on a minimum tax rate $t^{l}$ that lies between the noncooperative equilibrium tax rates. Because country 1 is the low tax jurisdiction $\left(t_{1}^{n}<t_{2}^{n}\right)$, it chooses the lower bound $t^{l}$ as its best strategy ${ }^{23}$. Countries 2 and 3 anticipate the tax policy of country 1 and respond strategically. The resulting equilibrium tax rates are

$$
t_{1}^{l}=t^{l}, t_{2}^{l}=t_{3}^{l}=\frac{1}{7}\left(t^{l}+b+\varepsilon\right) .
$$

\footnotetext{
${ }^{22}$ It is easy to check that $W_{i}(i=1,2,3)$ is concave in $t_{i}$.

${ }^{23}$ This is because the social welfare function is concave in tax rates.
} 
The capital invested in the different countries is $k_{1}^{l}=\frac{3 b-4 t^{l}-4 \varepsilon}{7 b}$ and $k_{2}^{l}=k_{3}^{l}=\frac{2\left(b+t^{l}+\varepsilon\right)}{7 b}$. As $k_{i}^{l} \geq 0$, we impose $b \geq \frac{4 \varepsilon+4 t^{l}}{3}$. The corresponding welfare levels for each country are

$$
\begin{aligned}
W_{1}^{l} & =\frac{1}{98 b}\left(3 b-4 t^{l}-4 \varepsilon\right)\left(10 t^{l}+3 b-4 \varepsilon\right) \\
W_{2}^{l} & =W_{3}^{l}=\frac{4}{49 b}\left(t^{l}+b+\varepsilon\right)^{2} .
\end{aligned}
$$

Comparing cooperation with tax competition from the perspective of social welfare (comparing $W_{i}^{l}$ with $W_{i}^{n}$ ), we demonstrate that every country will be better off under cooperation if $t_{1}^{n}<t^{l}<\min \left\{\frac{17}{180}(3 b-4 \varepsilon), t_{2}^{n}\right\}$.

That is, the minimum tax rate must be higher than the lowest rate in the noncooperative case, but sufficiently low for all of the countries to benefit from cooperation.

\section{Competition in taxes and infrastructure}

In this section, we assume that the governments provide local firms with public goods intended to enhance the productivity of private capital. Countries thus compete both in taxes and the provision of infrastructure. The level of infrastructure provided by country $i(i=1,2,3)$ is denoted $g_{i}$. The results of the noncooperative competition will serve as a baseline to gauge the desirability of tax harmonization. In the spirit of Hindriks et al. (2008), the production function, which is specific to country $i(i=1,2,3)$ exhibits constant returns in infrastructure and takes the form

$$
F_{i}\left(k_{i}, g_{i}\right)=\left(a+g_{i}\right) k_{i}-\frac{b}{2} k_{i}^{2} .
$$

The cost function of the public input is given by $c_{i}\left(g_{i}\right)=\frac{g_{i}^{2}}{2}, i=1,2,3$. The convexity reflects that the provision of public infrastructure is increasingly difficult. The equilibrium share of capital located in each country is determined by the arbitrage condition

$$
\rho=f_{1}\left(k_{1}, g_{1}\right)-t_{1}=f_{2}\left(k_{2}, g_{2}\right)-t_{2}=f_{3}\left(k_{3}, g_{3}\right)-t_{3},
$$


where $f_{i}\left(k_{i}, g_{i}\right)=\left(a+g_{i}\right)-b k_{i}$ is the marginal product of capital in country $i$ and $\rho$ is the world interest rate. It follows that the amount of capital invested in country $i$ is

$$
k_{i}=\frac{1}{3}-\frac{\left(g_{h}+g_{j}-2 g_{i}\right)-\left(t_{h}+t_{j}-2 t_{i}\right)}{3 b}, h, j \neq i .
$$

The subscripts $h$ and $j(h, j=1,2,3)$ refer to the other two countries.

Each government selects the tax rate and level of infrastructure that maximize its welfare function

$$
\begin{aligned}
W_{i} & =F_{i}\left(k_{i}, g_{i}\right)-f_{i}\left(k_{i}, g_{i}\right) k_{i}+t_{i} k_{i}-\frac{g_{i}^{2}}{2} \\
& =\frac{b}{2} k_{i}^{2}+t_{i} k_{i}-\frac{g_{i}^{2}}{2} .
\end{aligned}
$$

In the following, we solve a two-stage game. In the first stage, countries select the public expenditure levels. Tax rates are set in the second stage for given infrastructure levels that are selected in the first stage ${ }^{24}$. We solve the game by backward induction.

\subsection{Tax game}

First, we focus on the tax game. It is easy to verify that the welfare function $W_{i}$ is concave in $t_{i}$. The best tax response of country $i$ is

$$
t_{i}=\frac{1}{8}\left[\left(g_{h}+g_{j}-2 g_{i}\right)+\left(t_{h}+t_{j}\right)+b\right], h, j \neq i .
$$

Because the reply functions are upward sloping, taxes are strategic complements. Note also that the slope is less than one, which ensures the stability of the equilibrium. By solving the system of equations (17), we derive the Nash equilibrium in taxes

$$
t_{i}=\frac{1}{18}\left[4 g_{i}-2\left(g_{h}+g_{j}\right)+3 b\right] .
$$

\footnotetext{
${ }^{24}$ The choice of sequentiality follows the rule that the most irreversible decision must be made first.
} 


\subsection{Infrastructure game}

At the first stage, each jurisdiction maximizes its payoff with respect to its infrastructure provision $g_{i}$. The FOCs yield

$$
g_{i}=\frac{8\left(2 g_{h}+2 g_{f}-3 b\right)}{81 b-32}, h, j \neq i .
$$

We require that $b>\frac{32}{81}$ to ensure that the objective functions in $g_{i}$ are concave. The equilibrium public expenditure of country $i$ is

$$
g_{i}^{* *}=\frac{8}{27} \text {. }
$$

Introducing (20) into the equations (18) yields the equilibrium tax rate of country $i$

$$
t_{i}^{* *}=\frac{b}{6}
$$

The amount of capital invested in country $i$ is $k_{i}^{* *}=\frac{1}{3}$. The welfare of country $i$ is then

$$
W_{i}^{* *}=\frac{1}{729}(81 b-32), i=1,2,3,
$$

which is positive because $b>\frac{32}{81}$.

\section{Partial tax harmonization}

In this section, we analyze whether partial tax harmonization is desirable. To that end, we assume that countries 1 and 2 form a tax union and set a common tax rate $t$ that maximizes their joint welfare. However, the member states of the union are assumed to select their infrastructure levels noncooperatively. This is because many infrastructure expenditures primarily satisfy internal policy goals and are incidentally attractive to foreign investments. Therefore, it is difficult to coordinate these types of sovereign decisions. Country 3 stays outside the union and observes the coalition of countries 1 and 2. The outsider competes with the union as a whole by providing infrastructure in the first stage and competes over tax rates in the second stage. We first solve the game, and then compare social welfare with and without tax policy coordination. 


\subsection{Competition with partial tax harmonization}

Beginning from the second stage, the FOCs in tax rates ${ }^{25}$ yield

$$
\begin{aligned}
t & =\frac{1}{6}\left(g_{1}+g_{2}-2 g_{3}+3 b\right), \\
t_{3} & =\frac{1}{12}\left(-g_{1}-g_{2}+2 g_{3}+3 b\right) .
\end{aligned}
$$

We observe that the larger the rate of decline of marginal productivity $b$, the higher the tax rate will be for a given level of public infrastructure provision. The reason is that the marginal productivity of capital is lower for a higher value of $b$, which results in a lower demand for capital. The competition for capital is relaxed, and tax rates increase.

In the first stage, the three countries compete in public infrastructure. Solving the FOCs with respect to $g_{i}$, we obtain the equilibrium levels of infrastructure provision

$$
\begin{aligned}
g_{1}^{u} & =g_{2}^{u}=\frac{23(9 b-4)}{18(24 b-13)}, \\
g_{3}^{u} & =\frac{2(36 b-23)}{9(24 b-13)} .
\end{aligned}
$$

To guarantee the concavity of $W_{i}$ in $g_{i}$, we impose $b>\frac{77}{144}$. This condition is fulfilled if we require that the level of infrastructure $g_{i}$ is nonnegative, which requires that $b>$ $\frac{23}{36}$. Substituting (24) into (23), we obtain the equilibrium tax rates

$$
\begin{aligned}
t^{u} & =\frac{4 b(9 b-4)}{3(24 b-13)}, \\
t_{3}^{u} & =\frac{b(36 b-23)}{6(24 b-13)} .
\end{aligned}
$$

It is easy to verify that the uniform tax rate within the union is higher than that of the outsider, $t^{u}>t_{3}^{u}$, as the union as a whole faces a lower tax elasticity of capital. However, to remain attractive, the tax union must provide more public infrastructure than the outsider. Indeed, we obtain $g_{1}^{u}=g_{2}^{u}>g_{3}^{u}$. The amount of capital located in

\footnotetext{
${ }^{25}$ It is easy to verify that $W_{1}+W_{2}$ is concave in $t$ and $W_{3}$ is concave in $t_{3}$.
} 
each country is

$$
\begin{aligned}
k_{1}^{u} & =k_{2}^{u}=\frac{2(9 b-4)}{3(24 b-13)}, \\
k_{3}^{u} & =\frac{36 b-23}{3(24 b-13)} .
\end{aligned}
$$

The resulting welfare levels are given as follows

$$
\begin{aligned}
W_{1}^{u} & =W_{2}^{u}=\frac{(9 b-4)^{2}(720 b-529)}{648(24 b-13)^{2}}, \\
W_{3}^{u} & =\frac{(36 b-23)^{2}(9 b-2)}{81(24 b-13)^{2}}
\end{aligned}
$$

which are positive when $b>\underline{b}=\frac{529}{720}$. In the following, we assume that condition $b>\underline{b}$ always holds.

\subsection{Comparing social welfare}

Because the member states of the union are identical, we can write

$$
\begin{aligned}
W_{1}^{u}-W_{1}^{* *} & =W_{2}^{u}-W_{2}^{* *} \\
& =\frac{32}{729}-\frac{b}{9}+\frac{(9 b-4)^{2}(720 b-529)}{648(24 b-13)^{2}}
\end{aligned}
$$

It is easy to check that $W_{i}^{u}-W_{i}^{* *}>0(i=1,2)$, if $b>\bar{b}$ where $\bar{b}=1.09$. Consequently, partial tax harmonization improves the welfare of countries 1 and 2 if the value of $b$ is sufficiently high. However, setting a uniform tax rate makes the union members worse off if $\underline{b}<b<\bar{b}$.

To understand the intuition underlying this result, first note that a "low" value of $b$ $(b<\bar{b})$ implies that the demand for capital and hence competition for capital is "high". However, when the value of $b$ is relatively "high" $(b>\bar{b})$, competition for capital is "low". Furthermore, when the union is constrained by a uniform tax rate, infrastructure competition becomes more pronounced than in the noncooperative case $\left(g_{i}^{u}>g_{i}^{* *}\right)$. 
Thus the intuition is straightforward. When international competition for capital is intense $(b<\bar{b})$, partial tax harmonization results in the over-use of costly infrastructure spending. The additional net output ${ }^{26}$ induced by an increased amount of infrastructure spending in the case of partial tax harmonization is overcompensated by the additional cost of providing infrastructure. Thus, agreeing on a common tax rate reduces the welfare of the union countries relative to the noncooperative scenario $\left(W_{i}^{* *}>W_{i}^{u}\right)$. However, when competition for capital is less intense $(b>\bar{b})$, partial tax harmonization improves the social welfare of the tax union $\left(W_{i}^{u}-W_{i}^{* *}>0, i=1,2\right)$, as the net output increase it induces exceeds the additional cost of providing infrastructure.

The following result can be stated

Proposition 1 If a subgroup of countries commits to a common tax rate but competes in infrastructure, social welfare in the tax union falls when $\underline{b}<b<\bar{b}$ and rises when $b>\bar{b}$ relative to noncooperative competition in taxes and infrastructure.

Now consider the impact of partial tax harmonization on the outsider's welfare. The welfare change in the nonmember state resulting from partial harmonization is

$$
W_{3}^{u}-W_{3}^{* *}=\frac{32}{729}-\frac{b}{9}+\frac{(36 b-23)^{2}(9 b-2)}{81(24 b-13)^{2}} .
$$

Solving $W_{3}^{u}-W_{3}^{* *}=0$ yields the unique ${ }^{27}$ root $\underline{b}<b^{m}=0.76$. Consequently, tax harmonization in the union increases the welfare of the nonmember state when $b>b^{m}$ but decreases its welfare when $\underline{b}<b<b^{m}$.

The underlying intuition can be explained as follows. When the value of $b$ is sufficiently low, $b<b^{m}$, the member states compete aggressively in infrastructure as we

\footnotetext{
${ }^{26}$ Indeed, it is convenient to write $W_{i}^{u}-W_{i}^{* *}=\Delta I_{i}-\Delta C_{i}(i=1,2)$, which means that the welfare change induced by the transition from noncooperative tax competition to partial harmonization results from a net output gain $\left(\Delta I_{i}=\left(F_{i}\left(k_{i}^{u}, g_{i}^{u}\right)-\rho^{u} k_{i}^{u}\right)-\left(F_{i}\left(k_{i}^{* *}, g_{i}^{* *}\right)-\rho^{* *} k_{i}^{* *}\right)\right.$ and a change in the cost of providing public inputs $\left(\Delta C_{i}=\frac{\left(g_{i}^{u}\right)^{2}}{2}-\frac{\left(i_{i}^{* *}\right)^{2}}{2}\right)$, where $\rho^{u}$ and $\rho^{* *}$ are interest rates with and without partial tax harmonization, respectively.

${ }^{27}$ We account for the condition that $b>\underline{b}$.
} 
highlighted above. This results in an over-provision of infrastructure by the union. Moreover, the infrastructure expenditures of the competing entities (union versus the outsider) are strategic substitutes ${ }^{28}$. Consequently, the outsider country will underprovide infrastructure and compete with low taxes. Eventually, the union attracts more capital than in the noncooperative case, and hence less capital flows to the nonunion country. As a result, the outsider's gain from lower investment costs ${ }^{29}$ does not compensate for the loss it incurs in net output. Accordingly, its social welfare decreases when countries 1 and 2 coordinate tax policy. When the value of $b$ is sufficiently high, $b>b^{m}$, the member states provide a relatively moderate level of infrastructure. Because infrastructure expenditures are strategic substitutes, the outsider will not substantially reduce its provision of public inputs, and tax competition will not be excessively intense. As a result, the outsider will attract sufficient capital ${ }^{30}$, and hence its social welfare will be higher than in the noncooperative case.

The following proposition concludes

Proposition 2 If a subgroup of countries commits to a common tax rate while competing in infrastructure, the social welfare of the nonmember state declines if $\underline{b}<b<b^{m}$ and increases when $b>b^{m}$ relative to noncooperative competition in taxes and infrastructure.

From Propositions 1 and 2, we can conclude the following. When $\underline{b}<b<b^{m}$, both the tax union and the outsider are worse off. When $b^{m}<b<\bar{b}$, the tax union is worse off while the nonmember state is better off. If $b>\bar{b}$, all of the countries benefit from the partial tax harmonization.

These results are at odds with the findings in pure tax competition (Konrad and

\footnotetext{
${ }^{28}$ The FOCs of the infrastructure game in the tax harmonization case yield the best response functions $g_{1}^{u}=g_{2}^{u}=\frac{-46 g_{3}+69 b}{144 b-46}$ for countries 1 and 2 and $g_{3}^{u}=\frac{-2 g_{1}^{u}+3 b}{9 b-2}$ for country 3.

${ }^{29}$ Similarly, we consider the decomposition $W_{3}^{u}-W_{3}^{* *}=\Delta I_{3}-\Delta C_{3}$, where $\Delta I_{3}$ and $\Delta C_{3}$ are the variations in the net output and the cost of infrastructure provision, respectively.

${ }^{30}$ Note that the world interest rate under partial tax coordination is lower than in the noncooperative game.
} 
Schjelderup, 1999) ${ }^{31}$, where partial tax harmonization is Pareto improving if the tax rates in the initial fully noncooperative equilibrium are strategic complements. They are also in contrast to the result obtained by Sørensen (2004) that all countries are better off with partial tax harmonization, although the union countries gain less than the outside country.

\section{A minimum tax rate}

In the previous section, we demonstrated that partial tax harmonization does not necessarily improve welfare in the tax union when countries compete in both taxes and infrastructure. Does the imposition of a minimum tax rate improve the member states' welfare? To answer this question, we assume that in a first stage, each country noncooperatively selects its level of public investment. In a second stage, each country sets its tax rate subject to a lower bound, which is imposed on the union countries. Country 3 is not subject to this tax constraint.

\subsection{Competition with a minimum tax rate}

As in the benchmark model (pure tax competition with asymmetric countries), we assume that $F_{1}\left(k_{1}, g_{1}\right)<F_{2}\left(k_{2}, g_{2}\right)=F_{3}\left(k_{3}, g_{3}\right)$ without loss of generality. The production function takes the form ${ }^{32}$

$$
\begin{aligned}
& F_{1}\left(k_{1}, g_{1}\right)=\left(a+g_{1}\right) k_{1}-\frac{b}{2} k_{1}^{2} \\
& F_{i}\left(k_{i}, g_{i}\right)=\left(a+g_{i}+\varepsilon\right) k_{i}-\frac{b}{2} k_{i}^{2}, i=2,3
\end{aligned}
$$

where $\varepsilon$ is positive.

\footnotetext{
${ }^{31}$ Our result also contradicts the finding in Conconi et al. (2008) that partial tax harmonization benefits all of the countries relative to the noncooperative case.

${ }^{32}$ The production function is similar to that in Hindriks et al. (2008).
} 
By analogy to section 3, we are able to demonstrate that country 1 is the low tax country if all countries choose the levels of their tax rates and infrastructure noncooperatively. Indeed, in equilibrium we obtain

$$
\begin{aligned}
& t_{1}^{n o n}=b\left(\frac{1}{6}-\frac{6 \varepsilon}{27 b-16}\right), \\
& t_{2}^{n o n}=t_{3}^{n o n}=b\left(\frac{1}{6}+\frac{3 \varepsilon}{27 b-16}\right),
\end{aligned}
$$

and $d^{33}$

$$
\begin{aligned}
& g_{1}^{\text {non }}=\frac{8}{27}-\frac{32 \varepsilon}{81 b-48}, \\
& g_{2}^{\text {non }}=g_{3}^{\text {non }}=\frac{8}{27}+\frac{16 \varepsilon}{81 b-48} .
\end{aligned}
$$

Therefore, if a minimum tax rate $\tau$ is agreed between countries 1 and 2, it only ${ }^{34}$ binds country 1 and induces it to choose this lower bound. Solving the game backwardly, where countries 1 and 2 cooperatively set a lower bound on taxes $\tau$, we obtain the equilibrium tax rates

$$
\begin{aligned}
& t_{1}^{\min }=\tau, \\
& t_{2}^{\min }=t_{3}^{\min }=\frac{3(\tau+b)(7 b-4)+21 b \varepsilon}{147 b-88},
\end{aligned}
$$

and the levels of infrastructure

$$
\begin{aligned}
& g_{1}^{\min }=\frac{4(\tau+b)(63 b-40)-336 b \varepsilon}{7 b(147 b-88)} \\
& g_{2}^{\min }=g_{3}^{\min }=\frac{40[(\tau+b)(7 b-4)+7 b \varepsilon]}{7 b(147 b-88)} .
\end{aligned}
$$

Concavity is guaranteed if $b>\frac{200}{441}$.

\footnotetext{
${ }^{33}$ The superscript "non" denotes value in the noncooperative equilibrium.

${ }^{34} \mathrm{We}$ only consider the case in which the minimum tax rate lies between the noncooperative equilibrium rates, as in Keen and Kanbur (1993).
} 


\subsection{Comparing social welfare}

Let $W_{i}^{\min }$ and $W_{i}^{n o n}$ denote the welfare of country $i$ with and without minimum tax coordination, respectively. The welfare difference is given by

$$
\begin{aligned}
\Delta W_{i} & =W_{i}^{\text {min }}-W_{i}^{\text {non }} \\
& =A_{i}(b) \tau^{2}+B_{i}(b, \varepsilon) \tau+C_{i}(b, \varepsilon),
\end{aligned}
$$

where $A_{i}(b)$ is a function ${ }^{35}$ of parameter $b . B_{i}(b, \varepsilon)$ and $C_{i}(b, \varepsilon)$ are functions of the parameters $b$ and $\varepsilon$. The roots of equation $W_{i}^{\min }-W_{i}^{\text {non }}=0$ can be positive, negative, or complex depending on the values of the parameters. Therefore, the imposition of a minimum tax can be welfare improving or welfare worsening for the countries inside and outside the union. To illustrate the impact of a lower tax bound on welfare, we provide simulations with different values for the parameter ${ }^{36}$ pair $(b, \varepsilon)$. The horizontal axis represents $\tau$, and the vertical axis denotes the change in welfare $\Delta W_{i}$, where $\Delta W_{2}=\Delta W_{3}$.

First, we set $b=1$ and consider different values of $\varepsilon$. When $\varepsilon=0.1$, we show in Figure 1(a) that the low tax country always loses, while the high tax country (Figure 1 (b)) always gains. However, in Figure 2 when $\varepsilon=0.3$, the low tax country can gain if the lower tax bound is not excessively high, and countries 2 and 3 lose if the bound $\tau$ is excessively low.

\footnotetext{
${ }^{35} A_{1}(b)<0$, and $A_{2}(b)=A_{3}(b)>0$.

${ }^{36}$ For each figure, $\tau$ begins at its minimum value, i.e., the noncooperative equilibrium tax rate of country 1 , as we assume that the lower bound lies between the two noncooperative equilibra.
} 


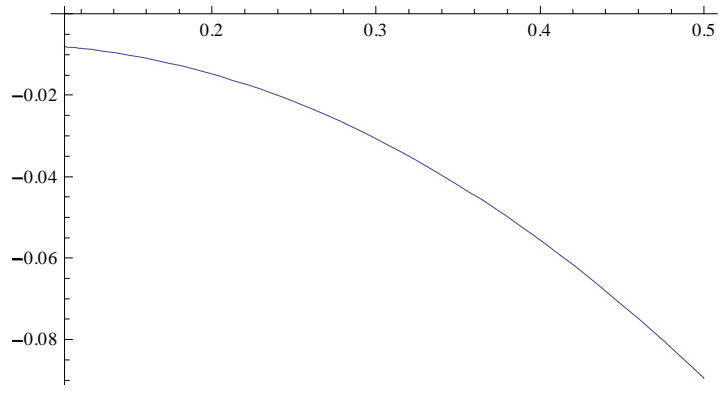

Figure 1(a) social welfare change for country $1, \varepsilon=0.1$

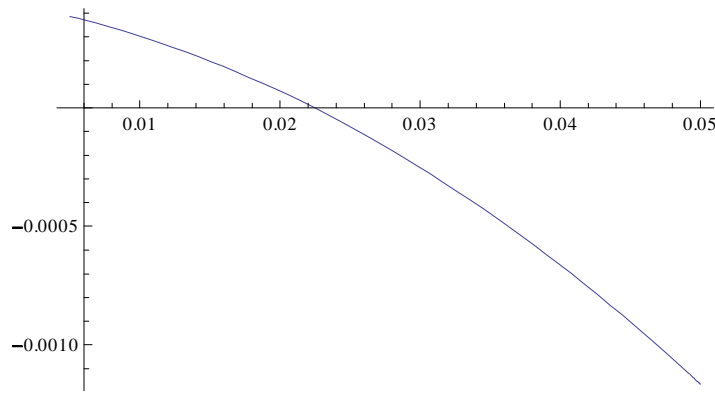

Figure 2(a) social welfare change for country $1, \varepsilon=0.3$

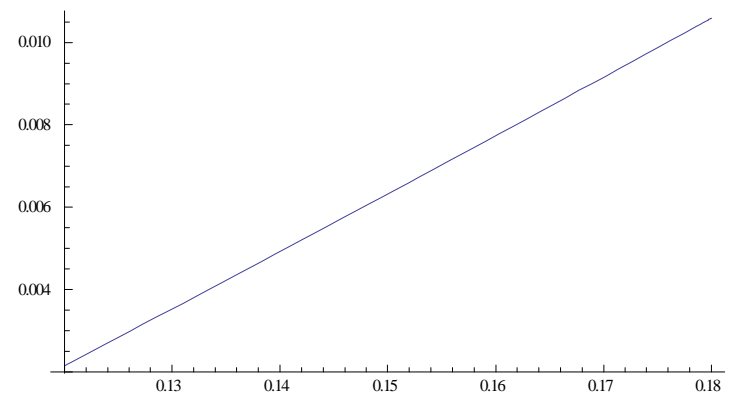

(b) social welfare changes for countries 2 and $3, \varepsilon=0.1$

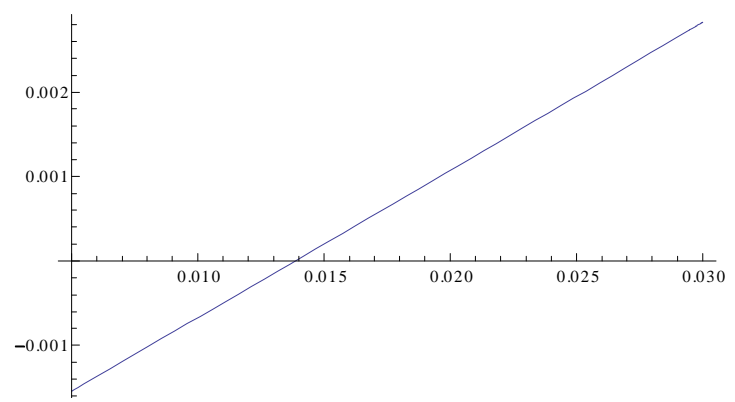

(b) social welfare changes for countries 2 and $3, \varepsilon=0.3$

We then set $\varepsilon=0.2$ and consider different values of $b$. Figure 3 demonstrates that when $b=0.8$, the low tax country loses if the minimum tax rate is excessively high, while countries 2 and 3 always gain. However, Figure 4 (a) illustrates that country 1 is always worse off if $b=1.0$, while the high tax countries (Figure 4 (b)) can be harmed if the lower tax bound is not sufficiently high. 


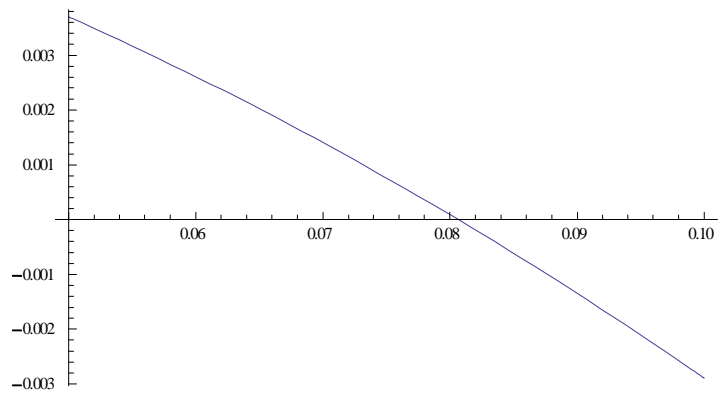

Figure 3(a) social welfare change for country $1, b=0.8$

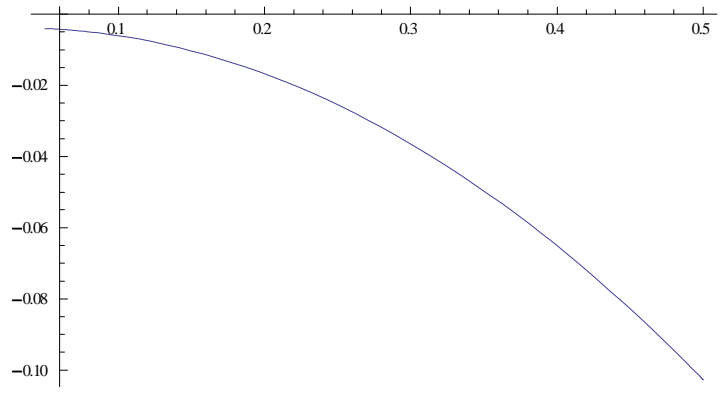

Figure 4(a) social welfare change for country $1, b=1.0$

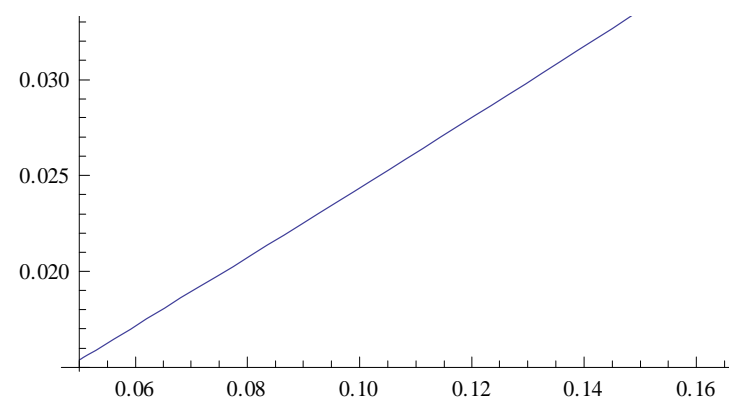

(b) social welfare changes for countries 2 and $3, b=0.8$

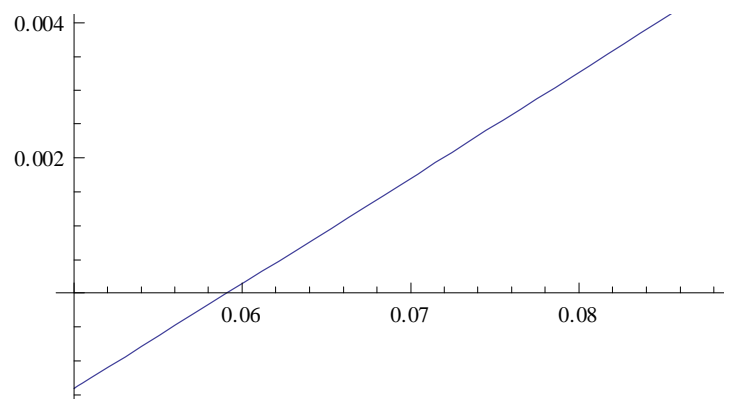

(b) social welfare changes for countries 2 and $3, b=1.0$

The results highlighted by the above simulations are in contrast to those resulting from pure tax competition when a minimum tax rate is imposed. When countries only compete in taxes, we have shown that all of the countries can be better off as long as the minimum tax is not excessively high. However, our simulations reveal cases where the imposition of a lower tax bound does not necessarily improve the social welfare of the member sates ${ }^{37}$ when the minimum tax rate is sufficiently low. It can even harm the high tax countries ${ }^{38}$, which differs from the findings of Sørensen $(2001,2004)$, who

\footnotetext{
${ }^{37}$ This result still holds when country 1 is the more advanced country. We can demonstrate this in a similar way and the proof is available upon request.

${ }^{38}$ Note that the high tax countries could be member or nonmember states.
} 
shows that establishing a minimum tax rate only harms the low tax country. When the tax bound is sufficiently high, the welfare effects depend crucially on the values of parameters $b$ and $\varepsilon$.

We state the results in the following proposition

Proposition 3 When countries compete in taxes and infrastructure, the imposition of a sufficiently low tax bound within a subgroup of countries does not necessarily improve the social welfare of the tax union. It can even harm both the high and low tax countries.

\section{Conclusion}

In this paper, we investigate the welfare implications of partial tax coordination when countries compete strategically in taxes and infrastructure. In a three-country model, we assume that two countries form a union and only coordinate their tax policy, while they compete in the provision of infrastructure. Moreover, the tax union competes with the nonunion country both in taxes and infrastructure. After assuming that all of the countries are identical, we first analyze the welfare effects of the establishment of a uniform tax rate within the union. We then explore the welfare effects of a lower bound on taxes when the member states are asymmetric in their levels of development.

We demonstrate first that partial tax coordination can harm both the member and nonmember states. Essentially, partial tax coordination allows the member states to freely compete in infrastructure for foreign direct investment while, to some extent, preventing them from defending their competitive situation in a globalized economy. Second, we demonstrate that the high tax country can also be made worse off under partial coordination, which contrasts with the general belief that only the low tax country loses. This could be a caveat for high tax countries such as France and Germany, which are pushing the European Union to speed up tax coordination efforts ${ }^{39}$. Finally,

\footnotetext{
${ }^{39}$ As first stated in the Financial Times (May 2, 2003, p2), which was then followed by a report in the Irish Examiner (an Irish national daily newspaper) on January 18, 2012, indicating that Germany and
} 
our results suggest that low productivity countries should opt for tax harmonization. Indeed, our results show that tax harmonization among these countries leaves them better off.

When the taxation polices of states are subject to policy coordination, their expenditure decisions are unfettered. To be in a favorable position regarding the constraints of tax coordination, the competing jurisdictions may choose to be a leader or a follower in infrastructure competition. Future research should address the desirability of tax coordination by endogenizing the timing of infrastructure decisions.

France are pushing the EU to speed up tax coordination efforts, despite Irish and British opposition, and will soon make proposals to harmonize corporate tax rates. The call is contained in a document to be discussed at the EU summits on January 30 and in March of 2012. 


\section{References}

[1] Beaudry P., P. Cahuk and H. Kempf, 2000. Is it harmful to allow partial cooperation? The Scandinavian Journal of Economics 102, 1-21.

[2] Boadway R. and J.F. Tremblay, 2011. Reassessment of the Tiebout model. Journal of Public Economics 96, 1063-1078.

[3] Bucovetsky S., 2009. An index of capital tax competition. International Tax and Public Finance 16, 727-752.

[4] Bucovetsky S., 1991. Asymmetric tax competition. Journal of Urban Economics 30, 167- 181.

[5] Bucovetsky S. and M. Smart, 2006. The efficiency consequences of local revenue equalization: tax competition an tax distortions. Journal of Public Economic Theory $8,119-144$.

[6] Burbidge J. and K. Cuff, 2005. Capital tax competition and returns to scale. Regional Science and Urban Economics 35, 353- 373.

[7] Burbidge B., J.A. DePater and G. M. Myers, 1997. A coalition-formation approach to equilibrium federations and trading blocs. The American Economic Review 87, 940-956.

[8] Conconi P., C. Perroni and R. Riezman, 2008. Is partial tax harmonization desirable? Journal of Public Economics 92, 254-267.

[9] Hauptmeier S., F. Mittermaier and J. Rincke, 2012. Fiscal competition over taxes and public inputs. Regional Science and Urban Economics 42, 407-419.

[10] Hindriks J., S. Peralta and S. Weber, 2008. Competing in taxes and investment under fiscal equalization. Journal of Public Economics 92, 2392-2402. 
[11] Itaya J., M. Okamura and C. Yamaguchi, 2008. Are regional asymmetries detrimental to tax coordination in a repeated game setting? Journal of Public Economics 92, 2403-2411.

[12] Justman M., J.F. Thisse and T. V. Ypersele, 2002. Taking the bite out of fiscal competition. Journal of Urban Economics 52, 294-315.

[13] Keen M. and R. Kanbur, 1993. Jeux sans frontieres: tax competition and tax coordination when countries differ in size. The American Economic Review 83, 877-892.

[14] Keen M. and K. A. Konrad, 2012. International tax competition and coordination. Max Planck Institute for Tax Law and Public Finance, working paper.

[15] Kempf H. and G. Rota-Graziosi, 2010. Endogenizing leadership in tax competition. Journal of Public Economics 94, 768-776.

[16] Koethenbuerger M., 2011. How do local governments decide on public policy in fiscal federalism? Tax vs. expenditure optimization. Journal of Public Economics 95, 1516-1522.

[17] Konrad K. A., and G. Schjelderup, 1999. Fortress building in global tax competition. Journal of Urban Economics 46,156-167.

[18] Machlup F., 1991. Economic Semantics (2nd edition). New Brunswick, Transaction Publishers, 161.

[19] Marchand M., P. Pestieau and M. Sato, 2003. Can partial fiscal coordination be welfare worsening? A model of tax competition. Journal of Urban Economics 54, 451-458.

[20] Peralta S. and T. Van Ypersele, 2005. Factor endowments and welfare levels in an asymmetric tax competition game. Journal of Urban Economics 57, 258-274.

[21] Peralta S. and T. Van Ypersele, 2006. Coordination of capital taxation among asymmetric countries. Regional Science and Urban Economics 36, 708-726. 
[22] Pieretti P. and S. Zanaj, 2011. On tax competition, public goods provision and jurisdictions' size. Journal of International Economics 84, 124-130.

[23] Sørensen P.B., 2001. Tax coordination in the European Union: what are the issues? Swedish Economic Policy Review 8, 143- 195.

[24] Sørensen P.B., 2004, International tax coordination: regionalism versus globalism. Journal of Public Economics 88, 1187-1214.

[25] Wildasin D.E., 1991. Some rudimetary 'duopolity' theory. Regional Science and Urban Economics 21, 393-421.

[26] Wilson J.D., 1986. Theories of tax competition. National Tax Journal 52, 269-304.

[27] Wilson J.D., 1991. Tax competition with interregional differences in factor endowments. Regional Science and Urban Economics 21, 423- 452.

[28] Wilson J.D., 1999. A theory of interregional tax competition. Journal of Urban Economics 19, 296-315.

[29] Wilson J.D. and D.E. Wildasin, 2004. Capital tax competition: bane or boon. Journal of Public Economics 88, 1065- 1091.

[30] Zissimos B. and M. Wooders, 2008. Public good differentiation and the intensity of tax competition. Journal of Public Economics 92, 1105-1121.

[31] Zodrow G.R. and P.M. Mieszkowsky, 1986. Pigou, property taxation and the underprovision of local public goods. Journal of Urban Economics 19, 356-370. 